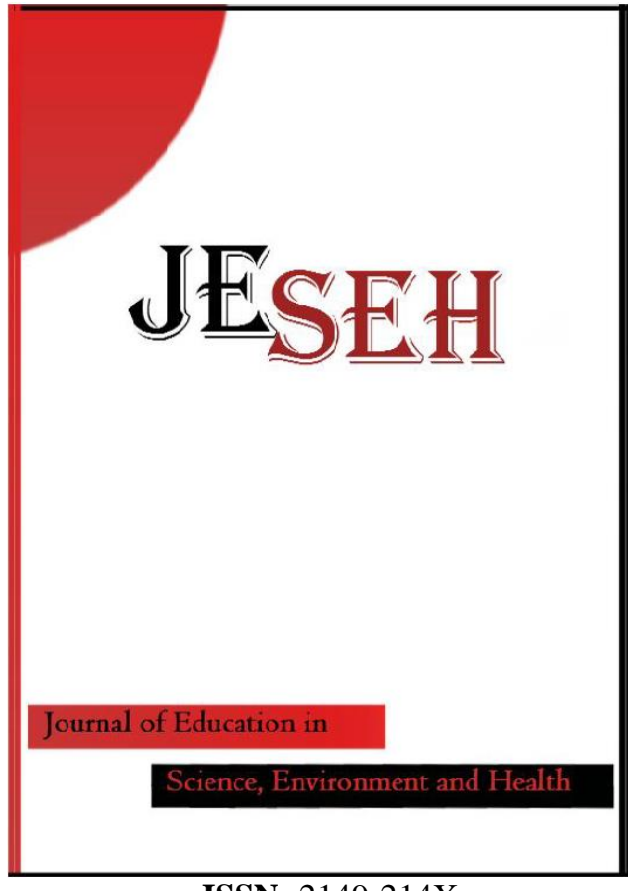

ISSN: $2149-214 \mathrm{X}$

\section{Journal of Education in Science,} Environment and Health

\author{
www.jeseh.net
}

Examination of Students' Small Groups Discussion in Argumentation Process: Scientific and Socio-Scientific Issues

\section{Esra Kabatas-Memis ${ }^{1}$, Ebru Ezberci-Cevik ${ }^{2}$}

${ }^{1}$ Kastamonu University

${ }^{2}$ Erciyes University

To cite this article:

Kabatas-Memis, E. \& Ezberci-Cevik, E. (2017). Examination of students' small groups discussion in argumentation process: Scientific and socio-scientific issues. Journal of Education in Science, Environment and Health (JESEH), 3(2), 126-137. DOI: $10.21891 /$ jeseh.325788

This article may be used for research, teaching, and private study purposes.

Any substantial or systematic reproduction, redistribution, reselling, loan, sub-licensing, systematic supply, or distribution in any form to anyone is expressly forbidden.

Authors alone are responsible for the contents of their articles. The journal owns the copyright of the articles.

The publisher shall not be liable for any loss, actions, claims, proceedings, demand, or costs or damages whatsoever or howsoever caused arising directly or indirectly in connection with or arising out of the use of the research material. 


\title{
Examination of Students' Small Groups Discussion in Argumentation Process: Scientific and Socio-Scientific Issues
}

\author{
Esra Kabatas-Memis, Ebru Ezberci-Cevik
}

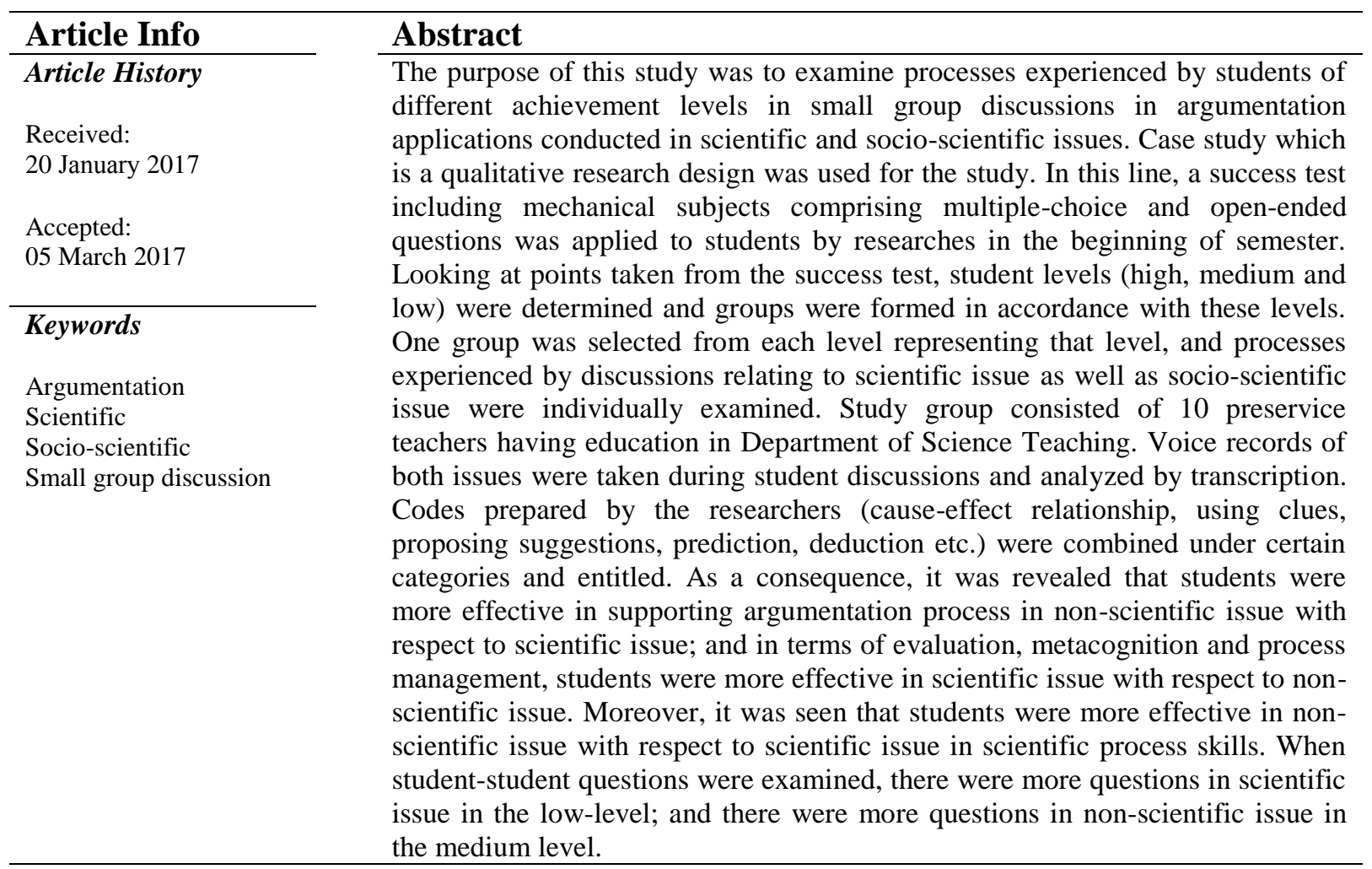

\section{Introduction}

Argumentation applications are a part of targets of constructivist science classes and are based on social constructivism (Jiménez-Aleixandre, 2007). Argumentation is a discourse form regarded as important in education (Kuhn, 1993). It may be expressed as a discourse form in which individuals determine their locations, defend a situation with claims and evidences, and express potential arguments (Anderman \& Anderman, 2009). Argumentation represents a process in which propositions are supported, justified and proved. It is the basic thought in this process to reveal a justified result and to attempt to prove this result (Norris, Phillips \& Osborne, 2008). Argumentation in science enables revealing inconsistencies between thought and evidences and eliminating them (Berland \& Hammer, 2012). Due to these reasons, argumentation should be rendered as a part of science and should be integrated into science education (Erduran \& Jiménez-Aleixandre, 2007). Science education programs (National Research Council [NRC], 1996; Ministry of National Education [MNE],2013) highlight the necessity of improving skills in discussion in scientific or socio-scientific issues, performing analyses and making knowledge-based decisions by students, and study based on argumentation places the inquiry in center.

Students should be given opportunities to attend in applications of science in learning environments along with argumentation (Sampson, Enderle \& Grooms, 2013). Argumentation is not a beneficial skill only for science education, school courses, and scientific issues. It may also be used in every field as a key skill requiring answering questions with claims supported with evidences. Thus, inquiry based models in education are more than memorizing truths about science, rather a platform in which students learn argumentation skills to understand and explore natural world (Hand \& Schoerning, 2012). 
Argumentation normally comprises relevant assumptions relating to a problem and results thereof. Determination of advantages and disadvantages of a subject to reach certain results requires determination of conflictions on the subject. Argumentation helps students to constitute strong content knowledge and provides context for deepening knowledge (Anderman \& Anderman, 2009). In processes of deepening knowledge, students attempt to understand the reasons instead of simply accepting a situation. Students go beyond simply expressing a text or speech, and can provide a more complex and interrelated knowledge. Thus, knowledge gets more meaningful for students.

Argumentation is regarded as an important education for life and, when applied, value and importance thereof are revealed. Individuals attempt to solve a problem in argumentation process, examine a subject deeply and arrive at a decision by discussing together (Kuhn, 2005). Thusly, structuring of knowledge is enabled by paying attention to claims within the scope of alternatives (Anderman \& Anderman, 2009). During this argumentation process, students reply claims of others with their own claims and adverse claims, provide explanations, pose questions and feel the requirement of proving the opposite by refuting alternative ideas. When students pose questions about what they want to learn, they are more aware of what they do not know or astonished/surprised by this. Posing questions to themselves and their peers has a role as a "thought-initiator" and metacognition or epistemic tool, thereby structuring their thoughts (Chin \& Osborne, 2010). While individuals perform these activities, they have dialogue with peers, their teachers and sometimes with themselves to assess claims and evidences (Anderman \&Anderman, 2009).

Argumentation may be used in constituting and testing explanatory bases of knowledge as a teaching tool to improve learning. These processes are effective in improving thinking skills (Felton \& Khun, 2007). Argumentation helps students to fill blanks in understanding, questioning claim and evidences, and considering other points of view (Anderman \& Anderman, 2009). Kuhn (1993) stated that it was important that educators were present in discussion environments and allocated time for these discussion environments in class. Moreover, Kuhn (1993) highlighted that argumentation might be in inner/individual form in which individual could discuss by themselves and could arrange a series of thoughts in proving a claim and external/social form is a process in which two or more individuals discussed with the other. From this point of view, individual-form argumentation is a product, and a process in social form (Kuhn, 1993). Along with recent developments, argumentation theory shows that argument is a social field (Driver, Newton \& Osborne, 2000). Education programs should incorporate not only cognitive models but also social and cultural fields to improve argumentation processes. Hence, students gain social skills with argumentation applications in education (Driver, Newton \& Osborne, 2000). In order to do it, in this study applications were associated with scientific and socio-scientific issues.

Recently, argumentation has gained an important support in favor of inquiry learning. Inquiry Learning is an educational activity requiring taking positions in gathering information about the world by scientists. Students directly involve in their own research activities such as formulating hypotheses, designing experiments to test them, gathering information and writing their results (Keselman, 2003). Thus, they actively participate in acquisition of knowledge (de Jong \& van Joolingen, 1998). Inquiry Learning can be expressed as an educational activity in which a series of virtual or real facts are searched individually or as a group and in which results are acquired and written, and their causes and effects are determined (Kuhn, Black, Keselman \& Kaplan, 2000). Furthermore, natural world is used as a teaching strategy in catching the spirit of development of spirit and scientific inquiry (Bybee, 2004). Inquiry provides opportunities to make explanations and research for conceptualization of a problem in science education and its answer (NRC, 2000). This inquiry based education is regarded as important in raising effective 21 st century individuals who are problem-solvers, and have communication and thinking skills (MNE, 2013).

Scientific inquiry is closely related with scientific processes as well as being directly contributive to improvement of skills such as making observations, inferences, classifications, predictions, measurements, inquiry, interpretation and analysis of data. In scientific inquiry, socio-scientific issues may be used in supporting perceptions and reaching success in line with scientific literacy target (Lederman, Antink \& Bartos, 2012). Abd-El-Khalick (2003) stated that what was experienced by students in decision-making processes in socio-scientific subject-based learning environments was similar to processes experienced by confirmation of scientific information. These issues may be complicated, be controversial, not have one absolute right answer, be based on explanation and be open-ended (Sadler, 2004). Socio-scientific issues are current and authentic situations having a scientific base and a great importance for society (Ekborg, Ottander, Silfver \& Simon, 2013). Socio-scientific issues (for example, climate change, gene therapy, nuclear power, biological issues, etc.) are open ended social problems and strongly associated with science. Scientific information and inquiry applications may be used in negotiating socio-scientific issues. Tytler (2012) stated that modern science 
knowledge may also comprise unclear and complex socio-scientific issues. Socio-scientific issues, inquiry and negotiation enable integration of scientific concepts and processes with social structure and applications, thereby forming a strong context (Sadler, Barab \& Scott, 2007).

Socio-scientific inquiry has three main components as participation in story, structuring of writing and scientific inquiry (Barab et al., 2007). Socio-scientific inquiry contributes to interpretation of socio-scientific story/narrative/events and skills for understanding charts, tables and diagrams comprising interpretation of scientific writings. It gives clues about epistemologies of individuals via complexity and dynamics in socioscientific problems conceptualized by individuals (Barab et al., 2007).

Scientific and socio-scientific issues can be used in argumentation studies. Students provide active participation in inquiry/argumentation process within the frame of these issues, they act like scientists in this process (AbdEl-Khalick, 2003; de Jong \& van Joolingen, 1998; Keselman, 2003). Furthermore, it provides important gains in line with purposes of scientific conceptualization and scientific literacy (Lederman, Antink \& Bartos, 2014; Sadler, Barab \& Scott, 2007). In studies based on socio-scientific issues, it was highlighted that it helped students understand science concepts better (Klosterman \& Sadler, 2010), helped in improvement of a positive attitude of students towards science by making learning attractive and it positively affected epistemologies (Zeidler, Sadler, Applebaum \& Callahan, 2009). It is also similar in scientific issues centered argumentation applications. It was stated that it helped in better learning and making sense of scientific concepts by students (Hand, Wallace \& Yang, 2004; Schroeder, 2008; Kabataş Memiş, 2014) and progression of metacognitive thinking (Grimberg, 2008; Kabataş Memiş \& Seven, 2015) and development of positive attitude of students towards science (Hand, Wallace \& Yang, 2004). Thus, two issues were determined in this study as scientific and socio-scientific issue. Small group discussions reflecting perceptions of members of groups (Young \& Henquinet, 2000) determined within the scope of these issues were examined in terms of different achievement levels experienced in the argumentation process.

\section{Method}

In this research aiming to examine experiences in the argumentation processes of the students in the scientific and socio-scientific issues, the case study was based as one of qualification research patterns. The case study method includes deep examination of a single situation or event instead of examining limited number of variables and following certain rules (Davey, 1991). Case studies are ways to look what really happens in environments, systematically collecting data, analyzing and revealing results thereof. In this study, assessment of the argumentation process performed in the scientific and socio-scientific issues in terms of the different achievement levels was realized.

\section{Participant}

The study was conducted with 25 prospective teachers having education in Science Education of an intermediate-scale university in north of Turkey in fall semester of 2013-2014 academic years. Students determined small groups to study on their own in the beginning of semester without any teacher interference. Seven different groups were formed, each comprising 3 or 4 students. Three different groups (totally 10 students) were selected and constructed working group of this study. The working group was determined by purposive sampling method. The reason behind the preference of this method was the advantage of incorporation of the most appropriate groups for purpose of study into the study (Balc1, 2013; Çepni,2014). Furthermore, while working in collaboration, the students were asked to create their own groups to prevent the process from negative effects of binary relations.

\section{Groups' Achievement Level}

Mechanics subject-based success test was applied prior to application to determine mechanics subject-based achievement levels of the students. There are 28 multiple-choice and 7 concept questions in the test prepared by researchers. The test questions were selected as appropriate for levels of students from different sources and examinations made by ÖSYM (ÖSS and ÖSYS). For provision of scope and structure validity, expert opinions in physics and language fields were taken and required corrections were made on the test. Cronbach's alpha reliability coefficient of the test was determined as .71. Answer keys were formed for concept questions and concept questions were graded by masking student names by an expert in their fields independent of researchers. 
Distribution of questions in the achievement test in accordance with cognitive steps is given in indication table (see Table 1).

Table 1. Mechanics subject based success test indication table

\begin{tabular}{|c|c|c|c|c|c|c|}
\hline \multirow[b]{2}{*}{ Subject } & \multicolumn{6}{|c|}{ Cognitive Level } \\
\hline & Knowledge & Comprehension & Application & Analysis & Synthesis & Evaluated \\
\hline Density & & $\begin{array}{c}8,11,12,15,18 \\
\text { A3, A4 }\end{array}$ & $\begin{array}{c}9,13,14,16 \\
17\end{array}$ & $10, \mathrm{~A} 5$ & & \\
\hline Force & & $\begin{array}{l}4,11 \\
\text { A1 }\end{array}$ & $1,2,3,5,6,7$ & 10 & & \\
\hline Linear Motion & & $19,20,21,22$ & & & & \\
\hline $\begin{array}{l}\text { Projectile } \\
\text { Motion }\end{array}$ & 25 & 24 & 23 & A6,A7 & & $\mathrm{A} 2$ \\
\hline $\begin{array}{l}\text { Energy and } \\
\text { conservation }\end{array}$ & & 26 & $27,28,29$ & & & \\
\hline
\end{tabular}

Achievement levels of student groups were determined based on points taken from mechanics subject-based success test. Study of Akkuş, Günel and Hand (2007) was taken as reference on determination of the achievement levels. Taking averages and standard deviations of points taken from the test for achievement levels into consideration, groups with low achievement level( $\mathrm{X}^{-}-1 /(4) \mathrm{SD}$ and below), medium achievement level $\left(X^{-}-1 /(4)\right.$ SD,$X^{-}+1 /(4)$ SD $)$ and high achievement level $\left(X^{-}+1 /(4)\right.$ SD and upper) were defined. In this context, it may be expressed that 3 groups were in low achievement level, 2 groups in medium achievement level and 2 groups in high achievement level. Groups randomly selected from each achievement level was examined within the scope of this study. There were totally three students ( 2 male, 1 female) in low achievement level, four students ( 3 female, 1 male) in medium achievement level and three students ( 3 female) in high achievement level examined within the scope of study. This achievement level is considered to form the study groups. When we look at the literature, for National Assessment Governing Board (as cited in Akkuş, Günel and Hand, 2007) using a method to define student performance standards. Therefore, this method identifies what students should know and think and also be able to do at each level (basic, proficient, and advanced). In other study, Yerrick (2000) was to examine the effects of open inquiry instruction with low achieving. Thus, in this study researchers grouped students in such a way.

\section{Argumentation Applications}

Students have carried out science laboratory applications within the period of applications as appropriate for argumentation. In these applications, students experienced preparing questions, making experiments, forming claims and evidences one by one. On doing so, students performed small group discussions. Afterwards, large group discussions were made by sharing claims and evidences with the whole class. Within the scope of this study, small group discussions were carried out for socio-scientific (biological-based) and scientific (horizontal force) issue. Based on the SWH approach student template, the applications in a course are basically stated below. In both scientific and socio-scientific issues, students followed this process.

\footnotetext{
Students prepared their own questions (Beginning ideas - What are my questions?)

Students made experiments in small group discussions (Tests - What did I do?)

Students formed claims using observation and experiments (Observations - What did I see? and Claims- What can I claim?)

Students supported their claims with evidences (Evidence - How do I know? Why am I making these claims?)

Students presented these claims and evidences to the other classmates in large group discussions.
}

Socio-scientific issues are issues that are complicated, open-ended, mostly controversial, and not having one absolute right answer (Sadler, 2004). These issues represent social conflictions comprising science (Sadler \& Zeidler, 2005). The text prepared for the socio-scientific issue of the argumentation application within the scope of the study was individually distributed to the students. After reading of the text by the students, they were asked to solve the problem in their groups. In the small group discussions, the students were expected to provide claims for the solution of the problem and support their claims with evidences given within the text. The given text comprised, as Sadler (2004) stated, a socio-scientific issue which did not have one absolute answer, was controversial and did not have only one right answer, was based on healthy life and balanced nutrition. Within 
the scope of this study, it was examined that experiences of students in not only scientific but also socioscientific issues in argumentation applications.

The researcher took the role of a guide when the students had trouble in understanding the scientific process with the aid of auxiliary questions by enabling them to think of different dimensions. While doing so, the teacher incorporated questions such as why, what for and how. Moreover, the teacher guided them with questions when the students had trouble. Also, the researcher incorporated questions to enable negotiation initiation and continuation of the students in this period. The students searched different dimensions of the issue in different groups. Afterwards, each of the groups presented to the other groups and the researcher what questions they tested, what kind of way they proceeded in, what were claims and evidences formed, and thus carried out large group discussions. As in the small group discussions, researcher enabled thinking, negotiating, and making inquiries by student by asking questions such as "Do/don't you agree with what our friends say?, and "Why?" in the whole class discussions. Sometimes he/she encouraged the students to ask questions.

The scientific issue was the issue of "horizontal force". The students tried to find questions for questions determined by them within the scope of this issue. The students performed their experiments on sub-subjects of force effect, friction force, factors affecting friction force relating to the force subject. Experiment arrangements for their own questions were prepared, and the students formed claims using observation and experiments. They supported their claims with evidences. They conducted these applications in small group discussions having the teacher as the guide. Then, they presented what they did, their claims and evidences to the other classmates in large group discussions. As in the socio-scientific issue, the teacher involved in the process by mostly helping reasoning.

\section{Data Analysis}

Voice records of the group were taken during the small group discussions. The recordings were made with permission form the students. These voice records were then decrypted and transformed into a written document on a computer medium. In assessment of the data in this study, discourse analysis was used. Discourse analysis is a method enabling the understanding of what is going on within the class from the dimensions of both the teacher and the students by means of deep examination of spontaneous (without researcher interference) conversations within the class and texts of these conversations.

In this study, written documents representing the process carried out in small groups. Coding in the study was performed considering argumentation process experienced by the students. Written documents were firstly independently coded by each researcher, and then codings were compared and differences between the codings were eliminated. Certain themes were formed after the coding. The themes were determined considering the process experienced in small groups (inquiry, justification, explanation, persuasion, cause-effect relationship, peer education, comprehension control, etc.). The themes determined are scientific process skills, evaluation, advanced level thinking, process management, argumentation process support and student-student questions.

\section{Threats to Internal Validity}

Possible threats to internal validity and the methods used to tolerate them were discussed below:

To control location threat, the researcher kept location the same for all groups. Thus, all groups had the application and tests at the same place. Mortality threat was controlled in this research study because there was no missing participants during the application. To control instrumentation, the test questions were presented in multiple-choice form. Therefore, instrument decay was eliminated by scoring procedure. Besides, voice redors were essay type, but it was used coding procedure from the literature review. So, this threat was controlled completely.

\section{Results}

The codes formed as a result of analyses of dialogues within small group discussions performed for two weeks by the students were combined and six different themes were formed. These themes are scientific process skills, evaluation, metacognitive thinking, process management, argumentation process supporting and student-student questions. In Chart 1, formed themes and total code numbers of groups of high, medium, low achievement level 
relating to scientific and socio-scientific issues are present. While presenting students statement, students in each group were coded both using group symbol (High: H, Medium: M and Low: L) and number $(1,2,3, \ldots$ etc). For instance, $\mathrm{H} 1$ represent high achievement level first student.

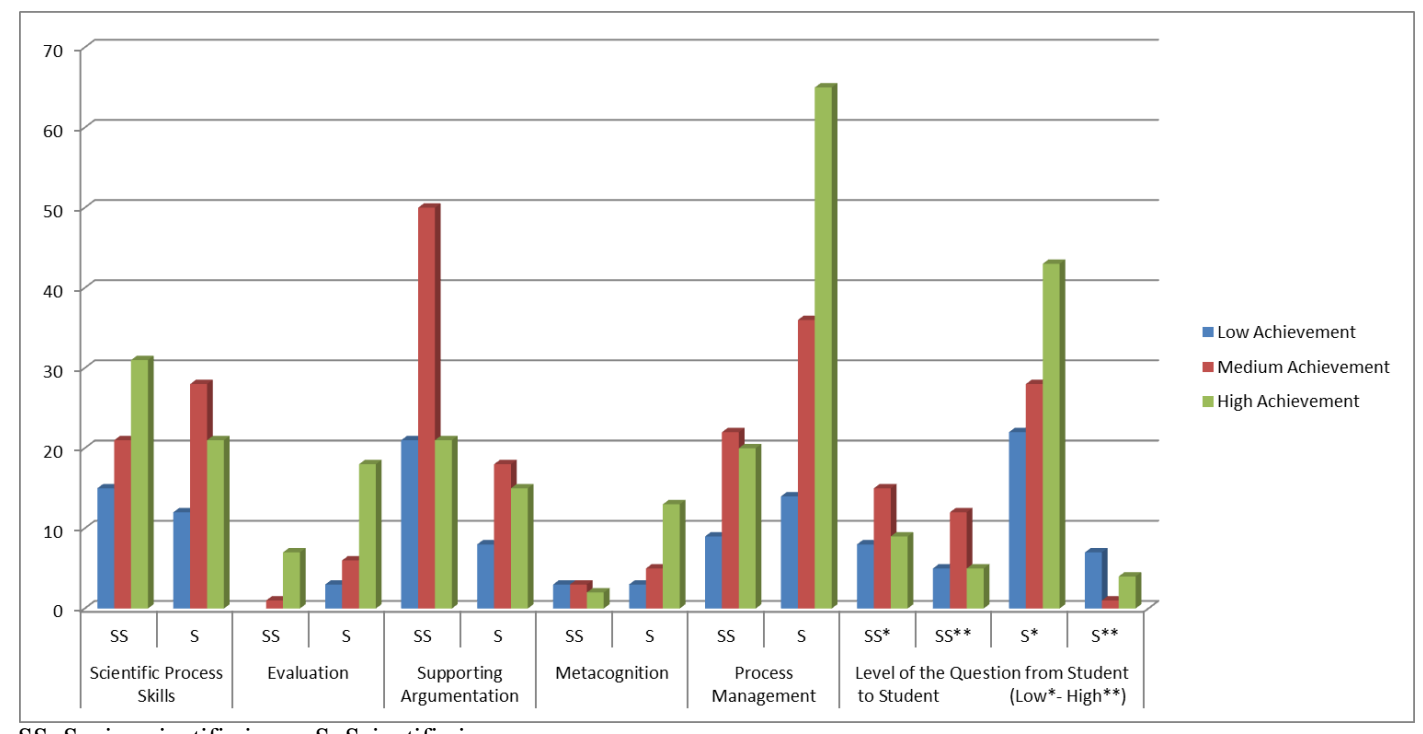

SS: Socio-scientific issue; S: Scientific issue

Chart 1. Results of three different groups about the themes

\section{Theme 1. Scientific Process Skills}

Scientific process skills theme consists of codes of "measurement, classification, observation, classification, prediction, inference, variable control, determination of variables, interpretation/argument, deduction, revealing of data, making references, exhibiting references to an authority, comparison, planning experiment arrangement, using pre-knowledge, explanation (communication)". When Chart 1 was examined, it was seen that the students in low and high achievement levels conducted situations reflecting scientific process skills better with respect to the scientific issue. As the opposite in the group of medium achievement level, the students incorporated statements in the scientific issue reflecting scientific process skills more than the socio-scientific issue.

Table 1. Coding samples relating to scientific process skills theme

\begin{tabular}{|c|c|c|}
\hline Issue & Groups & $\begin{array}{c}\text { Coding Samples } \\
\text { "Statement relating to code" / code / students }\end{array}$ \\
\hline \multirow{3}{*}{ Scientific } & High & $\begin{array}{l}\text { "This is our glass. We thought it would break, but it may not. I think it will } \\
\text { probably be broken" / prediction / } \mathrm{H}_{3}\end{array}$ \\
\hline & Medium & The object go once pulled. It can go forever" / deduction / $\mathrm{M}_{4}$ \\
\hline & Low & $\begin{array}{l}\text { We said gravity force exists, and there is a reaction force against it" / } \\
\text { variable control } / \mathrm{L}_{3}\end{array}$ \\
\hline \multirow{3}{*}{$\begin{array}{l}\text { Socio- } \\
\text { scientific }\end{array}$} & High & Is it possible? Can he throw himself on the glass?" / argument/ $H_{l}$ \\
\hline & Medium & Maybe he is schizophrenic, he did it himself." /interpretation/ $\mathrm{M}_{2}$ \\
\hline & Low & The guy is paranoid and very rich, he may have enemies /prediction $/ \mathrm{L}_{1}$ \\
\hline
\end{tabular}

On comparison of the groups of three different achievement levels, the students of high achievement level mostly incorporated such statements in the socio-scientific issue and the students of medium achievement level in the scientific issue while it is experienced the least commonly in the group of low achievement level in both issues. With the change applied in 2013, it was aimed to develop scientific process and life skills of students in a program arranged as a science-teaching program as well as developing scientific thinking habits with socioscientific issues (MNE, 2013). In this context, teaching of scientific and socio-scientific issues with argumentation-based application may be stated to be effective in the development of scientific process skills in students. Coding samples of the groups are given in Table 1. 


\section{Theme 2. Evaluation}

When dialogues of the students in the small group discussions were examined, it was determined that there were statements representing the codes of "evaluation, self-evaluation and peer evaluation". An evaluation theme was formed combining these codes. When Chart 1 was examined, it was remarkable that the students in all three achievement levels incorporated evaluation statements in the scientific issue with respect to the socio-scientific issue more. The students in high achievement level incorporated evaluation statements in socio-scientific issues more with respect to the students in the other two achievement levels; however, no evaluation statement was detected in student dialogues in low achievement level. Looking from this angle, as Alaçam-Akşit (2011) stated, the students may be said to be insufficient in making evaluation. Coding samples of the groups are indicated in Table 2.

Table 2. Coding samples relating to evaluation theme

\begin{tabular}{|c|c|c|}
\hline Issue & Groups & $\begin{array}{c}\text { Coding Samples } \\
\text { "statement relating to code"/code / students }\end{array}$ \\
\hline \multirow{3}{*}{ Scientific } & High & "I don't remember the net force." / self-evaluation / $\mathrm{H}_{3}$ \\
\hline & Medium & "You didn't pull fast. You pulled fast here." / peer evaluation / $\mathbf{M}_{4}$ \\
\hline & Low & $\begin{array}{l}\text { "That's what we said. There is gravity force downwards, there is an opposite } \\
\text { reaction force." / evaluation } / \mathrm{L}_{3}\end{array}$ \\
\hline \multirow{3}{*}{$\begin{array}{l}\text { Socio- } \\
\text { scientific }\end{array}$} & High & "You scrutinize it. Because the man may have eaten little or a lot according to \\
\hline & Medium & $\begin{array}{l}\text { his hunger status." / peer evaluation } / \mathrm{H}_{1} \\
\text { "Either sometime broke in from the window by hitting on the glass or he broke } \\
\text { the window, then killed himself." / evaluation } / \mathrm{M}_{2}\end{array}$ \\
\hline & Low & - \\
\hline
\end{tabular}

\section{Theme 3. Supporting Argumentation Process}

For argumentation process supporting theme, "claim, evidence, rebuttal, justification, inquiry, persuasion, nonadoption-resistance, cause-effect" codes were combined. As discussions occurred during the socio-scientific issues enable the suggestion of different opinions, along with being beneficial for the argument (Simonneaux, 2007), the argumentation based inquiry approach is effective in explaining and making sense of science concepts of students in the scientific issues and experiencing the scientific discussion (Akkuş et al., 2007). When results relating to argumentation process supporting theme in Chart 1 were examined, it was seen that students in all three achievement levels experienced a situation such as inquiry, cause-effect, resistance, persuasion, using justified statements and refutation (of himself and his peers) in the socio-scientific issue with respect to scientific issue. While the students of high and medium achievement levels incorporated such statements in similar ratios, the students of low achievement level incorporated such statements less than the other two groups. Coding samples of the groups are seen in Table 3.

Table 3. The coding examples of the theme for supporting the argumentation process

\begin{tabular}{|c|c|c|}
\hline Issue & Groups & $\begin{array}{c}\text { Coding Samples } \\
\text { "statement relating to code"/code / students }\end{array}$ \\
\hline \multirow{3}{*}{ Scientific } & High & $\begin{array}{l}\text { "It is impossible. Look what Songül says. F- } f_{s}=\text { fnet oh! Fnet... the one } \\
\text { which is } 120 " / \text { rebuttal } / \mathrm{H}_{3}\end{array}$ \\
\hline & Medium & $\begin{array}{l}\text { "There is no risk for our comparison as the weight is identical, the same } \\
\text { thing is happening" / cause-effect / } \mathrm{M}_{4}\end{array}$ \\
\hline & Low & "It is not like that, it has a friction coefficient."/ rebuttal / $\mathrm{L}_{1}$ \\
\hline \multirow[b]{2}{*}{ Socio-scientific } & High & "He fired his servant." / evidence / $\mathrm{H}_{2}$ \\
\hline & $\begin{array}{l}\text { Medium } \\
\text { Low }\end{array}$ & $\begin{array}{l}\text { "If he is thinking in that way, he would not leave the knife." / rebuttal / } \mathrm{M}_{3} \\
\text { A knife with blood thereon. / evidence / } \mathrm{L}_{2}\end{array}$ \\
\hline
\end{tabular}

\section{Theme 4. Metacognition}

Metacognition theme was created by combining the themes of "indecision, showing empathy, awareness raising and decision making". It was seen that when the chart was examined the statements which supported metacognition such as indecision, awareness raising decision-making were experienced maximally in the group that was in the high achievement level in scientific issue. It was understood that this group was followed by the 
students who were in the medium achievement level while the students who were in the low achievement level used such statements. It was seen that the groups were approximately equal in social-scientific issue. In this respect it was specified that the argumentation process supported metacognition usage of the students. Furthermore, it could be specified that when the relationship between the socio-scientific issues and the science education was considered, socio-scientific issues were important in understanding the advanced level thinking, discussion skills, scientific argumentation, inquiry based learning and the nature of science according to the needs of students (Nuangchalerm, 2010, s.36). The coding examples of each group are provided in Table 4.

Table 4. The coding examples of metacognition theme

\begin{tabular}{|c|c|c|}
\hline Issue & Groups & $\begin{array}{c}\text { Coding Samples } \\
\text { "statement relating to code"/code / students }\end{array}$ \\
\hline Scientific & $\begin{array}{l}\text { High } \\
\text { Medium } \\
\text { Low }\end{array}$ & $\begin{array}{l}\text { "I think this... how do I..." / indecision / } \mathrm{H}_{2} \\
\text { "It means it is changing" / awareness } / \mathrm{M}_{2} \\
\text { "I wonder if we apply less force or we get used to it." / indecision } / \mathrm{L}_{2}\end{array}$ \\
\hline $\begin{array}{l}\text { Socio- } \\
\text { scientific }\end{array}$ & $\begin{array}{l}\text { Medium } \\
\text { Low }\end{array}$ & $\begin{array}{l}\text { "And also under the table... if servant killed why did he put it under the table" / } \\
\text { indecision / } \mathrm{H}_{1} \\
\text { "Well, yes because he thinks like that, he sees like that, doesn't he..." / awareness } \\
\text { / } \mathrm{M}_{1} \\
\text { "It is ok then let's go to this way" /making decision / } \mathrm{L}_{2}\end{array}$ \\
\hline
\end{tabular}

\section{Theme 5. Management Process}

A process management theme was created by combining the codes of giving instruction, peer education, proposal/alternative suggestion, giving consent, asking for a proposal, using clues, giving clues, comprehension control and peer support. It was seen that when the chart 1 was examined the statements reflecting the process management theme were seen more in the scientific issue compared to socio-scientific issue. On the basis of groups in scientific issue the students in the high achievement level were the ones who used the statements relating to the process management maximally while this was encountered minimally in the students in the low achievement level. In socio-scientific issue the students who were in the high and medium achievement level used these statements in a similar ratio while these statements were used minimally in the group in the low achievement level. The coding examples of the groups are provided in Table 5.

Table 5. The coding examples of the management process theme

\begin{tabular}{|c|c|c|}
\hline Issue & Groups & $\begin{array}{c}\text { Coding Samples } \\
\text { "statement relating to code"/code / students }\end{array}$ \\
\hline \multirow{3}{*}{ Scientific } & High & "I agree that this is good." /peer support / $\mathrm{H}_{2}$ \\
\hline & Medium & $\begin{array}{l}\text { For example should those have the same size, right? /asking for consent / giving } \\
\text { consent } / \mathrm{M}_{3}\end{array}$ \\
\hline & Low & $\begin{array}{l}\text { " } L_{3} \text { ! Look at the coefficients of the friction force or something like that / giving } \\
\text { instruction/ } L_{2}\end{array}$ \\
\hline \multirow[b]{2}{*}{$\begin{array}{l}\text { Socio- } \\
\text { scientific }\end{array}$} & High & $\begin{array}{l}\text { "He was also saying that there has been a blood y knife, right?" / giving consent / } \\
\mathrm{H}_{2}\end{array}$ \\
\hline & $\begin{array}{l}\text { Medium } \\
\text { Low }\end{array}$ & $\begin{array}{l}\text { Yes, I also think the same thing/ peer support / peer support / } \mathrm{M}_{1} \\
\text { "If we eliminate the trauma, then we can say he died because of cuts" /suggesting } \\
\text { alternative / } \mathrm{L}_{1}\end{array}$ \\
\hline
\end{tabular}

\section{Theme 6. Student-Student Questions}

Students' questions were coded as low level (comprising short answers such as yes/no) questions and medium level (requiring explanation) questions. It was specified that the questions functioned as a basis during the process such as inquiry, discussing and decision making about an issue (Hand, 2008), and the students were required to ask qualified questions in order to create a question-claim-evidence triad. It was seen that when student-student questions were examined in chart 1 high level questions were used more in scientific issue whereas medium level questions were used more in socio-scientific issue. The students in the high achievement level used low level questions quite a lot in scientific issue and similarly, in socio-scientific issue low level questions were used more than the medium level questions. When the groups of medium and low level were examined (see chart 1) it was understood that a similar situation was experienced and the students used more 
low level questions than the medium level questions. The coding examples of the groups are provided in Table 6.

Table 6. The coding examples of student-student questions theme

\begin{tabular}{|c|c|c|}
\hline Issue & Groups & $\begin{array}{c}\text { Coding Samples } \\
\text { "statement relating to code"/code / students }\end{array}$ \\
\hline \multirow{3}{*}{ Scientific } & High & "Is it $m$ times a?" / low level question / $\mathrm{H}_{3}$ \\
\hline & Medium & "Do you know?” / low level question / $\mathrm{M}_{3}$ \\
\hline & Low & $\begin{array}{l}\text { "Does the friction force have less impact after it is applied?" / medium level } \\
\text { question / } \mathrm{L}_{1}\end{array}$ \\
\hline \multirow{4}{*}{ Socio-scie } & High & "Could he do this with panic?" / low level question / $\mathrm{H}_{1}$ \\
\hline & Medium & "But then how did he handle the fingerprints?" / medium level question / $\mathrm{M}_{3}$ \\
\hline & & \\
\hline & Low & $\begin{array}{l}\text { "How do we find without saying anything about the position of the chair and } \\
\text { the table because the smallest hair can be an evident?" / medium level } \\
\text { question / } \mathrm{L}_{2}\end{array}$ \\
\hline
\end{tabular}

\section{Discussion}

When the research results were considered it was seen that the students who were in high achievement level were more active in scientific issue (horizontal force), evaluation and process management. In scientific process skills and argumentation process supporting themes the students who were in medium achievement level executed this process more often while the ratios used by the students who were in different achievement level in the high-level thinking were close to each other. In this respect it could be specified that the argumentation applications performed by the students who were in different achievement level in scientific issue played an important role in small group discussions. It was determined that in the research carried out by Akkus et al.(2007) taking into consideration the achievement level the applications of argumentation based inquiry approach had a positive effect on the students' achievement. In similar studies in the literature it was specified that argumentation based inquiry approach had a positive effect on explanation of science concepts/conceptual understanding for the students (Keys, Hand, Prain \& Collins, 1999; Kıngır, Geban \& Günel, 2012).

On the other hand it was seen that when socio-scientific issue was considered, scientific process skills, evaluation and high-level thinking were experienced more often by the students in the high achievement level compared to the students in the medium achievement level whereas these were experienced more often by the students in the medium achievement level compared to the students in the lower achievement level. In the argumentation process supporting theme and process management it was detected that the students in the medium achievement level were more active. It was said that socio-scientific issue was a broad term which encompassed STS (science-technology-society) and required taking into consideration the ethical aspects of science and moral conditions and affective development of a child (Zeidler et al., 2002). Socio-scientific issues which were assumed as an important approach in the science education had a functional role in understanding the science concepts, argumentation skill development, critical thinking, inquiry development and decision making skills, and moral/ethic value adding (Molinatti, Girault, \& Hammond, 2010; Sadler \& Zeidler, 2005; Zeidler vd., 2002). Metacognition is an important factor in raising individuals who are aware of their own mental process and learn more consciously (Çakıroğlu, 2007). The studies indicate that inquiry applications in which the argumentation is used are efficient for students to develop high-level thinking skills and to learn and implement the science (Hand,Prain \&Wallace, 2002; Hand, Wallace \& Yang, 2004; Keys, Hand, Prain \& Collins, 1999).

Another theme in the study was student-student questions. With reference to student-student questions low level questions were used in scientific issue whereas medium-level questions were used in socio-scientific issue. When the students' dialogs were considered in the environments in which the inquiry process was experienced in this process it was important that students asked questions to each other in terms of understanding inquiry that was inherent for the science (Hofstein, Navon, Kipnis, \& Mamlok-Naaman, 2005). In addition, asking question helps to direct the different dialogs in order to solve the problems encountered (Aguiar, Mortimer \& Scott, 
2010). Blonder (2007) who focused on the questioning behaviors of the high school students interested in the research-inquiry reported that asking question helped student to reach a certain purpose and to be successful in lessons in which these questions were created. A similar situation was seen in this study. Because as students asked more questions they might experience much more guidance, inquiry and criticizing, and they can get result more readily. During this process with the applications within the triad of question-claim-evidence in the class, the students used and developed their thinking skills much better (Kana, 2014). Besides small and big group discussions were important for students to express themselves and to get different point of views by asking questions to each other.

According to the results obtained, it can be said argumentation skill were important in terms of inquiry development, critical thinking, decision making etc. In the science curriculum for primary schooling the relevance of the use of argumentation is emphasized in the adopted strategies and methods (MNE, 2013). Besides, one of the inquiry learning process in the curriculum focuses on the creating argument. On the other hand, in many important exams, such as in the PISA report, argumentation is included (Organization for Economic Co-operation and Development [OECD], 2001). In this sense, skill to assess claim and evidence were particular importance. In the present study, it was seen that emphasizing the importance of this, applying the argumentation practices in teaching in both scientific and socio-scientific issues are necessary.

Generally, it was concluded that during the process all applications based on socio-scientific issue along with the scientific issue contributed to the development of argumentation skill of the students in all levels. As the sciences in which the argumentation skill were important in terms of raising science-literate individuals were highlighted in the education program it could be suggested that socio-scientific issue could be used more along with scientific issue to develop such skills in the program (MNE, 2013). In addition it is thought that the seminars (along with exemplary applications) which will be held for the teachers in this issue will enable this approach to be used more often by the teachers.

\section{References}

Abd-El-Khalick, F. (2003). Socioscientific issues in pre-college science classrooms: The primacy of learners' epistemological orientations and views of nature of science. In D. L. Zeidler (Ed.), The role of moral reasoning in socioscientific issues and discourse in science education (pp. 41-61). Dordrecht, The Netherlands: Kluwer.

Aguiar, O. G., Mortimer, E. F., \& Scott, P. (2010). Learning from and responding to students' questions: The authoritative and dialogic tension. Journal of Research in Science Teaching. 47(2), 174-193.

Alaçam-Akşit, A. C. (2011). Sınıf öğretmeni adaylarının sosyobilimsel konularla ve bu konuların öğretimiyle ilgili görüşleri (Yüksek lisans tezi, Ege Üniversitesi, İzmir).

Akkuş, R., Günel, M., \& Hand, B. (2007). Comparing an inquiry-based approach know as the science writing heuristic to tradational science teaching practices: are there differences. International Journal of Science Education, 1-21.

Anderman, E. M. \& Anderman, L. H. (Ed.) (2009). Psychology of classroom learning: An encyclopedia. Detroit: Macmillan Reference USA.

Balcı, A. (2013). Sosyal Bilimlerde Araştırma: Yöntem, Teknik ve İlkeler.10. Baskı, Pegem Akademi, Ankara.

Barab,S., Zuiker, S., Warren, S., Hickey, D., Ingram-goble, A. Kwon,E., Kouper, I., \& Herring,S.C. (2007). Science Education, 91(5), 750-782.

Berland, L. K., \& Hammer, D. (2012). Framing for scientific argumentation. Journal of Research in Science Teaching, 48 (1),68-94.

Besnard, P., \& Hunter, A. (2008). Elements of Argumentation. Cambridge, MA: MIT Press.

Bybee, R. W. (2004). Scientific inquiry and science teaching. In L. B. Flick, \& N. G. Lederman (Eds.), Scientific inquiry and nature of science (pp. 1- 14). Dordrecht, The Netherlands: Kluwer Academic Publishers.

Chin, C., \& Osborne, J. (2010). Supporting argumentation through students' questions: Case studies in science classrooms. Journal of the Learning Sciences, 19(2), 230-284.

Çakıroğlu, A. (2007). Üstbiliş. Türkiye Sosyal Araştırmalar Dergisi, 11 (2).

Çepni, S. (2014). Araştırma ve Proje Çalışmalarına Giriş. Yedinci baskı, Trabzon.

Çolakoğlu K. (Ed.). (2002). Serway fen ve mühendislik için fizik (5. Bask1). Ankara: Palme Yayıncılık

de Jong, T., \& van Joolingen, W. R. (1998). Scientific discovery learning with computer simulations of conceptual domains. Review of Educational Research, 68(2), 179-201.

Davey, L. (1991). The application of case study evaluations. Practical Assessment, Research \& Evaluation, 2(9), 1-2. 
Driver, R., Newton, P., \& Osborne, J. (2000). Establishing the norms of scientific argumentation in classrooms. Science Education, 84(3), 287-312.

Ekborg, M. , Ottander, C., Silfver, E., \& Simon, S. (2013). Teachers' experience of working with socioscientific issues: A large scale and in depth study. Research in Science Education, 43(2), 599- 617. doi: 10.1007/s11165-011-9279-5

Felton, M. K., \& Kuhn, D. (2007). "How Do I Know?" The Epistemological Roots of Critical Thinking. The Journal of Museum Education, 32(2), 101-110.

Hand B. M. (2008). Introducing the science writing heuristic approach. B. M., Hand (Ed.). Science inquiry, argument and language içinde( ss.1-11). Rotterdam: Sense Publisher.

Hand, B., \& Schoerning, E. (2012). The Discourse of Argumentation. Mevlana International Journal of Education (MIJE), 2(3), 43-52.

Hand, B., Prain, V., \& Wallace, C. (2002). Influences of writing tasks on students' answers to recall and higherlevel test questions. Research in Science Education, 32,19-34.

Hand, B., Wallace, C., \& Yang, E. (2004). Using the science writing heuristic to enhance learning outcomes from laboratory activities in seventh grade science: Quantitative and qualitative aspects. International Journal of Science Education, 26, 131-149.

Hofstein, A., Navon, O., Kipnis, M., \& Mamlok-Naaman, R. (2005). Developing students' ability to ask more and better questions resulting from inquiry-type chemistry laboratories. Journal of research in science teaching, 42(7), 791-806.

Jimenez-Aleixandre, M. P. (2007). Designing argumentation learning environments. S. Erduran ve M. P. Jiménez-Aleixandre (Ed.) Argumentation in science education:Perspectives from classroom-based research içinde (ss. 91-115). Dordrecht: Springer.

Jimenez-Aleixandre, M. P., \& Erduran, S. (2007). Argumentation in science education: An overview. S. Erduran and M. P. Jiménez-Aleixandre (Ed.) In Argumentation in science education: Perspectives from classroom-based research (pp. 3-27). Dordrecht: Springer.

Kabataş Memiş, E. (2014). Elementary Students' Ideas About On Implementation Of Argumentation Based Science Learning Approach. Kastamonu Education Journal, 22(2), 1-18.

Kabataş Memiş, E., \& Seven, S. (2015). Effects of an SWH Approach and Self-Evaluation on Sixth Grade Students' Learning and Retention of an Electricity Unit. International Journal of Progressive Education, 11(3), 32-49

Kana, F. (2014). The effect of argumentation-based language teaching approach pre-service Turkish language teacher attitudes to special teaching methods course. International Journal of Language Academy, 2(1), 107-125.

Keselman, A. (2003). Supporting inquiry learning by promoting normative understanding of multivariable causality. Journal of Research in Science Teaching, 40 (9), 898-921.

Keys, C. W., Hand, B., Prain, V. \& Collins, S., (1999). Using the science writing heuristic as a tool for learning from laboratory investigations in secondary science. Journal of research in science Teaching, 36(10), 1065-1084.

Kıngır, S., Geban, Ö., \& Günel, M. (2011). Öğrencilerin kimya derslerinde argümantasyon tabanlı bilim öğrenme yaklaşımının kullanılmasına ilişkin görüşleri. Selçuk Üniversitesi Ahmet Keleşoğlu Eğitim Fakültesi Dergisi, 32, 15-28.

Kuhn, D. (1993). Science as argument: Implications for teaching and learning scientific thinking.

Science Education, 77, 319-337.

Kuhn, D. (2005). Education for thinking. Cambridge, MA: Harvard University Press.

Kuhn, D., Black, J., Keselman, A., \& Kaplan, D. (2000). The development of cognitive skills to support inquiry learning. Cognition and Instruction, 18(4), 495-523.

Lederman N.G., Antink, A., \& Bartos, S. (2012). Nature of science, scientific inquiry, and socio-scientific issues arising from genetics: A Pathway to developing a scientifically literate citizenry. Science \& Education, 23, 285-302. DOI 10.1007/s11191-012-9503-3

Klosterman, M. L., \& Sadler, T. D. (2010). Multi-level assessment of scientific content knowledge gains associated with socioscientific issues based instruction. International Journal of Science Education, 32, 1017-1043.

MNE (Ministry of National Education) (2013). "İlköğretim Kurumları Fen Bilimleri Dersi (3, 4, 5, 6, 7 ve 8. sınıflar) Öğretim Programı".

Molinatti, G., Girault, Y., \& Hammond, C. (2010). High School Students Debate the Use of Embryonic Stem Cells: The influence of context on decision-making. International Journal of Science Education, 32(16), 2235-2251.

Norris, S. P., Phillips, L. M., \& Osborne, J. F. (2008). Scientific inquiry: The place of interpretation and argumentation. In J. Luft, R. L. Bell, \& J. Gess-Newsome (Eds.), Science as inquiry in the secondary setting (pp. 87-98). Washington, DC: National Science Foundation. 
National Research Council. (1996). National science education standards. Washington, DC: National Academy Press.

Nuangchalerm, P. (2010). Development of Socio Scientific Issues-based Teaching for preservice science Teacher. Journal of social Sience, 5 (3), 239-243.

OECD (Organisation for Economic Co-operation and Development) (2001). Knowledge and skills for life. First results from PISA 2000. Organisation for Economic Co-operation and Development. Available at https://www.oecd.org/edu/school/programmeforinternationalstudentassessmentpisa/33691620.pdf (09.02.2017)

Potter, J. (2004). Discourse analysis as a way of analyzing naturally occurring talk. D. Silverman (Ed.) In Qualitative analysis: Issues of theory and method, 2nd Edition (pp. 200-221). London:Sage.

Sadler, T. D. (2004). Informal reasoning regarding SSI: A critical review of research. Journal of Research in Science Teaching, 41(5), 513-536.

Sadler, T. D., Barab, S. A., \& Scott, B. (2007). What do students gain by engaging in socioscientific inquiry? Research in Science Education, 37, 371-391.

Sadler, T. D., \& Zeidler, D. L. (2005). Patterns of informal reasoning in the context of socioscientific decision making. Journal of Research in Science Teaching, 42, 112-138.

Sampson, V., Enderle, P., \& Grooms, J. (2013). Argumentation in science and science education. The Science Teacher, 80(5), 30-33.

Schroeder, J. D. (2008). The lab-lecture correlation: From the Science Writing Heuristic to the Traditional Organic Chemistry Laboratory. In Science Inquiry Argument and Language: A Case for the Science Writing Heuristic by Brian M. Hand, Ed.; Sense Publihers, Rotterdam, the Netherlands 2008.

Tytler, R. (2012). Socio-scientific issues, sustainability and science education. Research in Science Education, 42, 155-163. DOI 10.1007/s11165-011-9262-1

Young, C. B., \& Henquinet, J. A. (2000). Viewpoint: A conceptual framework for designing group projects. Journal of Education for Business, 76(1), 56-60.

Zeidler, D. L., Sadler, T. D., Applebaum, S., \& Callahan, B. E. (2009). Advancing reflective judgment through socioscientific issues. Journal of Research in Science Teaching, 46(1), 74-101. doi: 10.1002/tea.20281

Zeidler, D. L., Walker, K. A., Ackett, W. A., \& Simmons, M. L. (2002). Tangled up in views: Beliefs in the nature of science and responses to socioscientific dilemmas. Science education, 86(3), 343-367.

\begin{tabular}{lc}
\hline & Author Information \\
\hline Esra Kabatas Memis & Ebru Ezberci Cevik \\
Kastamonu University & Erciyes University \\
Faculty of Education, Kastamonu, Turkey & Faculty of Education, Kayseri, Turkey \\
Contact e-mail: ekmemis@ kastamonu.edu.tr & \\
\hline
\end{tabular}

